\title{
Technoeconomical Assessment of Optimum Design for Photovoltaic Water Pumping System for Rural Area in Oman
}

\author{
Hussein A. Kazem, Ali H. A. Al-Waeli, Atma H. K. Al-Kabi, and Asma Al-Mamari \\ Faculty of Engineering, Sohar University, P.O. Box 44, 311 Sohar, Oman \\ Correspondence should be addressed to Hussein A. Kazem; h.kazem@soharuni.edu.om
}

Received 14 December 2014; Revised 16 March 2015; Accepted 17 March 2015

Academic Editor: Elias Stathatos

Copyright ( 2015 Hussein A. Kazem et al. This is an open access article distributed under the Creative Commons Attribution License, which permits unrestricted use, distribution, and reproduction in any medium, provided the original work is properly cited.

Photovoltaic (PV) systems have been used globally for a long time to supply electricity for water pumping system for irrigation. System cost drops down with time since PV technology, efficiency, and design methodology have been improved and cost of wattage drops dramatically in the last decade. In the present paper optimum PV system design for water pumping system has been proposed for Oman. Intuitive and numerical methods were used to design the system. HOMER software as a numerical method was used to design the system to come up with optimum design for Oman. Also, REPS.OM software has been used to find the optimum design based on hourly meteorological data. The daily solar energy in Sohar was found to be $6.182 \mathrm{kWh} / \mathrm{m}^{2} \cdot$ day. However, it is found that the system annual yield factor is $2024.66 \mathrm{kWh} / \mathrm{kWp}$. Furthermore, the capacity factor was found to be $23.05 \%$, which is promising. The cost of energy and system capital cost has been compared with that of diesel generator and systems in literature. The comparison shows that the cost of energy is $0.180,0.309$, and 0.790 USD $/ \mathrm{kWh}$ for PV-REPS.OM, PV-HOMER, and diesel systems, respectively, which sound that PV water pumping systems are promising in Oman.

\section{Introduction}

The continuous increase in electrical global demand and concern of environment due to pollution from human kind activities leads to exploring new and clean energy technology. Photovoltaics (PV) could be one of the important solutions since it is clean and renewable and tested for a long period of time. It is currently widely used for different applications. However, in the past the drawback of PV was their high initial cost in comparison with conventional energy systems. The situation has been changed due to increase of fossil fuel prices and on the other hand PV technology prices get down, efficiency has been increased, and manufacturing technology has been improved. The increase in efficiency reflected in the price of energy production. This could be on the level of manufacturing or on the level of system design. Optimization is very important to find the optimum system components. The typical system components of PV systems are as follows: PV module-array to generate DC power; charger, controller, and inverter to charge the storage battery and supply the AC load with power, respectively.
Different techniques are used for optimization of PV systems [1]. These techniques could be categorized into intuitive, numerical, and analytical techniques. In numerical technique many software applications are available to optimize energy systems. HOMER is one of these software applications. HOMER is used to investigate the feasibility of the PV system, which is developed by the National Renewable Energy Laboratory (NREL). Renewable and nonrenewable system could be modeled by HOMER. The algorithms of the software are used to evaluate the system to find the feasible system components in terms of technical and economical side views [2]. The author [1] designed MATLAB based user friendly software tool called the REPS.OM for optimal sizing of PV systems in Oman. The developed REPS.OM software tool aims to design PV system at minimum cost for Oman. REPS.OM calculates the optimum PV array-module tilt angle which is used to perform the optimization of PV system. In addition, it calculates the optimum inverter size for the PV system. Moreover, REPS.OM simulates the optimized PV system so as to investigate its performance for a period of one year. 
The application of optimization techniques for designing PV systems for water pumping and other applications can be found in [3-7]. In [3], the authors designed and investigated hybrid PV/diesel generator system using HOMER to supply village with energy consumption of $279 \mathrm{kWh} /$ day, in Ethiopia. The optimum design found $95 \%$ of energy to be provided by $\mathrm{PV}$ and 5\% from a diesel generator. The cost of the energy was found to be $0.401 \mathrm{USD} / \mathrm{kWh}$. In [4], the authors proposed water pumping system supplied by PV array in Algeria. They developed optimum design using MATLAB. The loss of power supply probability and life cycle cost are the two criteria used to judge the system technically and economically to find the optimum design. In $[5,6]$, the authors designed PV system to power lighting load for lab and typical house load in Oman, respectively. The authors used HOMER to find the optimum design and they claimed that the cost of energy is $0.561 \mathrm{USD} / \mathrm{kWh}$ and $0.389 \mathrm{USD} / \mathrm{kWh}$, respectively. In [7], the authors proposed optimum design of hybrid PV/biomass system using HOMER to supply village in India. The energy was used for cooking and to supply water pumping system for irrigation. The cost of energy was found to be 0.170 USD/kWh. In [8], there is a comparison study of PV and diesel generator supply water pumping system for irrigation in the Northern Badia of Jordan. LPSP concept has been used. Comparison of PV and diesel engine pumping systems shows that the cost is $0.20 \mathrm{USD} / \mathrm{m}^{3}$ and $0.58 \mathrm{USD} / \mathrm{m}^{3}$ for $\mathrm{PV}$ and diesel, respectively. It shows that the PV system is cost effective with respect to the diesel engine in rural area. But cost is differing from site to site. Also, it is found that different options could be used to supply water pumping systems in rural area. Standalone PV, diesel generator, or hybrid PV-diesel system is an option. In this paper the PV water pumping feasibility technical and economic analysis is presented for the system in Sohar, Oman. HOMER and REPS.OM software applications have been used for design and assessment, which contain a different system elements selection, cost of energy, and pollution.

\section{Sohar Solar Energy}

Sultanate of Oman lies between longitudes $51^{\circ} 50^{\prime} \mathrm{E}$ and $59^{\circ} 40^{\prime} \mathrm{E}$ and latitudes $16^{\circ} 40^{\prime} \mathrm{N}$ and $26^{\circ} 20^{\prime} \mathrm{N}$. Oman climatic conditions in general are desert in most regions and humid near the coast, which is $1700 \mathrm{~km}$ long. Also, Oman has 8.0-10.5 hours of daily sunshine duration, peak hours of $6.0-6.5,342$ sunny days, and average solar radiation of $5.197 \mathrm{kWh} / \mathrm{m}^{2} /$ day [1].

Sohar is the second large city in Oman and represents the heart of North Al-Batinah region. It falls in North Oman on $24 \mathrm{~N}$ and $56 \mathrm{E}$ latitude and longitude, respectively. Hourly solar radiation data was measured for complete year for this study. The WS-STD1 weather station has been installed on Renewable Energy Lab in Sohar University. The weather station comprises 11 sensors (solar global radiation, direct solar radiation, diffuse solar radiation, rain, wind speed and direction, solar energy, air temperature, ambient temperature, air pressure, and relative humidity), with $2 \mathrm{~m}$ mast, canopy, and accessories. Data logger was used to monitor and record the hourly data on computer for a complete year.
The measured solar radiation data are shown in Figure 2. The solar radiation in Sohar is various in the range of 3.2 to $6.2 \mathrm{kWh} / \mathrm{m}^{2} /$ day and in average of $5.55 \mathrm{kWh} / \mathrm{m}^{2} /$ day with high clearing index as shown in Figure 3.

\section{Sizing of PV Water Pumping Systems}

The PV systems are categorized based on the component configuration into grid connected and standalone systems. The grid connected system is used to generate and inject the energy directly to the utility grid. Examples of grid connected PV array found in house roof and large scale PV plants. The PV generates DC power which converted to AC with the same grid specifications; then it is integrated with the grid. The inverter was programmed and protected to take in consideration the grid cutoff situation. The grid connected systems not only are attractive for governments and industrial companies but also start to be attractive for individuals especially in countries that have feed in tariff.

The standalone PV system is mainly used in rural and isolated areas. It works independently for the grid to supply particular AC or DC loads. The stand-alone system could be an only PV array or it could connect with other renewable sources like wind, solar thermal, hydro-, geothermal systems, and so forth or it could be connected with nonrenewable sources like diesel, natural gas, and so forth. These hybrid systems are used widely as hybrid systems. The simple standalone PV system contains PV modules, batteries (optional) for storage with charge controller, and inverter in the case of AC load. Since the batteries are costly and need maintenance the PV module could be used directly to supply common loads on the day like water pumping systems [1].

$\mathrm{PV}$ water pumping in general is cost effective in rural area. It is an excellent choice for isolated and desert areas. Besides providing energy from PV to the water pumping system it has also reduced environmental pollution. On the other hand, pure drinking water and water use for irrigation are a critical need in rural area in developing countries such as Africa, Asia, and South America [9]. There is old history for water pumping system. Many methods have been used for pumping water utilizing different power sources. These sources are, namely, animal, human, hydro-, solar, and wind powers. Definitely the conventional engines use diesel or fossil fuel being also an option. Recently, due to the improvement in $\mathrm{PV}$ efficiency and reduction in PV prices solar PV became attractive to supply water pumping systems. Usually there are three different applications for PV water pumping systems: irrigation, livestock watering, and village water supply. In this section intuitive method was used to design PV water pumping system as shown in Figure 1.

3.1. Hydraulic Sizing. The essential information for hydraulic sizing is the required daily water volume, pumping head and hours per day, pipe length and material, and pump efficiency and pressure. The pumping power is calculated as follows [8]:

$$
P_{\text {pump }}=\frac{\rho g(h+\Delta H) Q}{\eta_{b} \cdot \eta_{e}},
$$




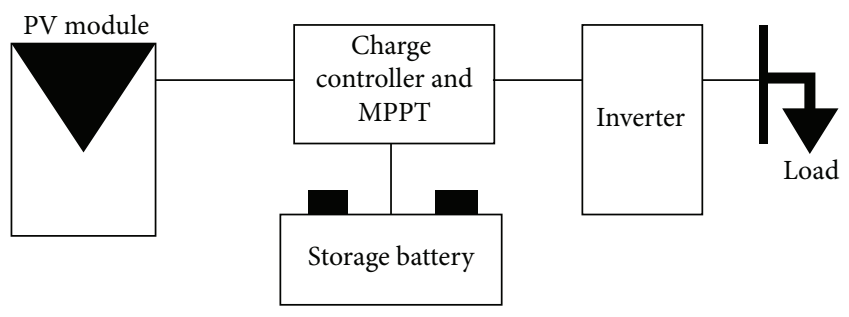

FIGURE 1: Typical PV system components.

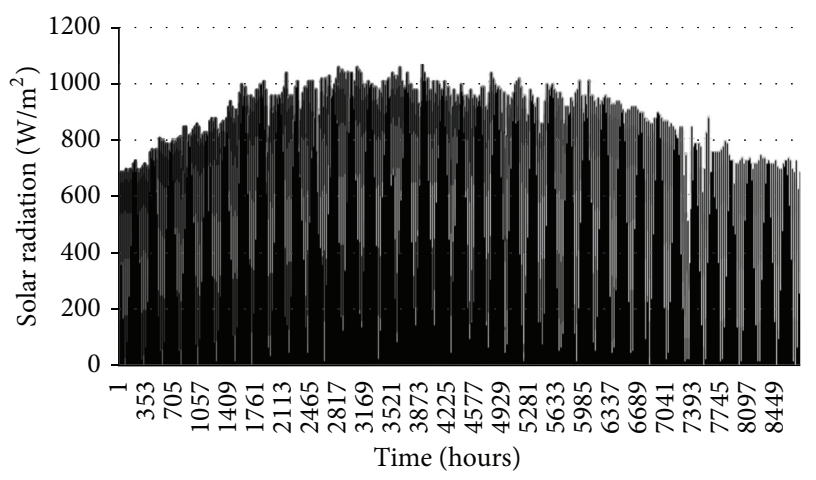

FIGURE 2: Mean hourly solar radiations for Sohar (April 2013-April 2014).

where $\rho$ is the water density $\mathrm{kg} / \mathrm{m}^{3}, g$ is acceleration due to gravity $\mathrm{m} / \mathrm{s}^{2}, h$ and $\Delta H$ are total pumping head and hydraulic losses in $\mathrm{m}$, volume of flow $Q$ in $\mathrm{m}^{3} / \mathrm{s}$, and $\eta_{b}$ and $\eta_{e}$ are pump and electric motor efficiencies, respectively.

Also, the required hydraulic energy in $\mathrm{kWh} /$ day is calculated as follows:

$$
E_{h}=\eta_{s} \cdot E_{\mathrm{PV}}=\rho g h V \eta_{s},
$$

where $V$ is the volume required in $\mathrm{m}^{3} /$ day, $\eta_{s}$ is the subsystem efficiency, and $E_{\mathrm{PV}}$ is the PV energy.

3.2. PV System Sizing. The PV array is used to convert solar energy to DC electrical energy. The quality of DC power improved through power conditioner and converted to AC power using an inverter. The energy produced by $\mathrm{PV}$ array in $\mathrm{kW}$ is calculated and is given by [10]

$$
E_{\mathrm{PV}}=A_{\mathrm{PV}} \times G_{T} \times \eta_{\text {module }} \times \eta_{\text {inv }} \times \eta_{\text {wire }},
$$

where $A_{\mathrm{PV}}$ is the area of the PV array in $\mathrm{m}^{2}$ and $G_{T}$ is daily solar radiation in $\mathrm{kWh} / \mathrm{m}^{2} ; \eta_{\text {module }}, \eta_{\text {inv }}$, and $\eta_{\text {wire }}$ are efficiencies of PV module, inverter, and wires, respectively. The area $A_{\mathrm{PV}}$ is calculated from (2) and (3) as follows:

$$
A_{\mathrm{PV}}=\frac{\rho g h V}{G_{T} \eta_{\mathrm{PV}} \eta_{s}}
$$

where $\eta_{\mathrm{PV}}$ is the summation of module, inverter, and wire efficiencies. Accordingly, the required PV array power is calculated in $\mathrm{kW}$ as follows:

$$
P_{\mathrm{PV}}=\frac{E_{h}}{G_{T} \cdot F \cdot E},
$$

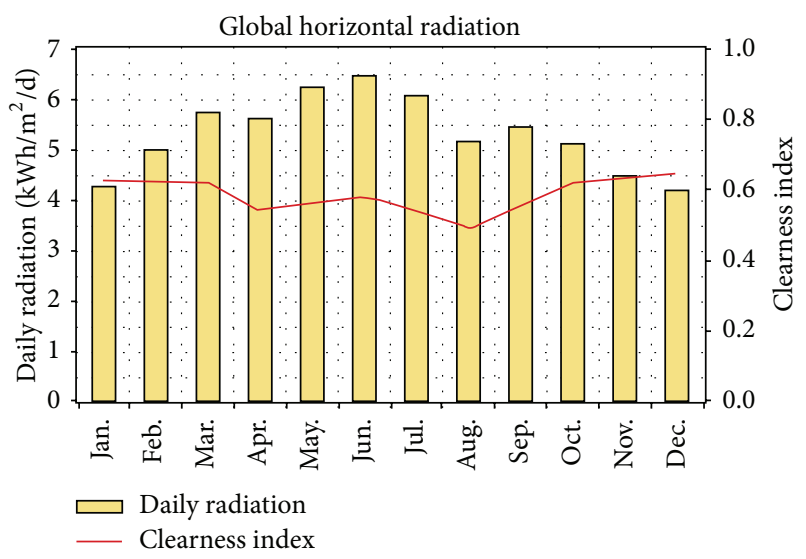

FIGURE 3: Profile of solar radiation in Sohar, Oman.

where $F$ is the mismatch factor which is in the range of $0.85-0.90$ and $E$ is the daily subsystem efficiency $0.2-0.6$ typically $[10,11]$. The PV/pump system efficiency is given by

$$
\eta_{\text {system }}=\frac{P_{h}}{P_{\mathrm{PV}}}=\frac{\rho g h V}{G_{T} A_{\mathrm{PV}}} .
$$

\section{PV Water Pumping Systems Components}

In this study the proposed system consists of PV array containing few modules, charge controller and inverter, batteries for storage, and the rest of system components like wires, protections, sensors, and module structure. The system configuration is shown in Figure 4. This figure shows the PV water pumping system proposed for irrigation in Sohar, Oman. It is worth mentioning that in this study the selected well depth is $16 \mathrm{~m}$, static water level is $6.5 \mathrm{~m}$, dynamic water level is $7.2 \mathrm{~m}$, well productivity is $8.1 \mathrm{~m}^{3} / \mathrm{h}$, design criteria are $4.5 \mathrm{~m}^{3} /$ day, and pump head is $18 \mathrm{~m}$. In the coming subsections HOMER software will be used first to find the optimum system design.

4.1. Water Pump. The intuitive method discussed in Sections 3.1 and 3.2 has been used to estimate the required PV system components. Equations (2) and (5) are used to calculate energy required for pumping water, which is $2.197 \mathrm{kWh} /$ day, and PV array is $0.88 \mathrm{~kW}$. Also, the motor pump was estimated to be $450 \mathrm{~W}, 230 \mathrm{~V}$, and $50 \mathrm{~Hz}$. It is worth mentioning that the pump works on peak hours.

4.2. PV Array. The solar cell is used to convert solar radiation into electricity. These cells are connected in series and are parallel to produce PV modules. The PV modules also connected series and are parallel to produce PV array. The proposed PV panels to be used in the system simulation are $140 \mathrm{~W}$ (at static test condition STC, insolation is $1000 \mathrm{~W} / \mathrm{m}^{2}$ and temperature $25^{\circ} \mathrm{C}$ ) and $12 \mathrm{~V}$ and have an estimated capital cost of USD 2.00/W and replacement cost of USD $1.07 / \mathrm{W}$. This cost includes mounting hardware, installation, commissioning, wiring, control system, dealer mark-ups, and shipping. The estimated lifetime is 25 years. A derating factor was selected to be of $90 \%$. In this analysis we considered the panels tilt angle to be $24^{\circ}$ (Sohar latitude). 


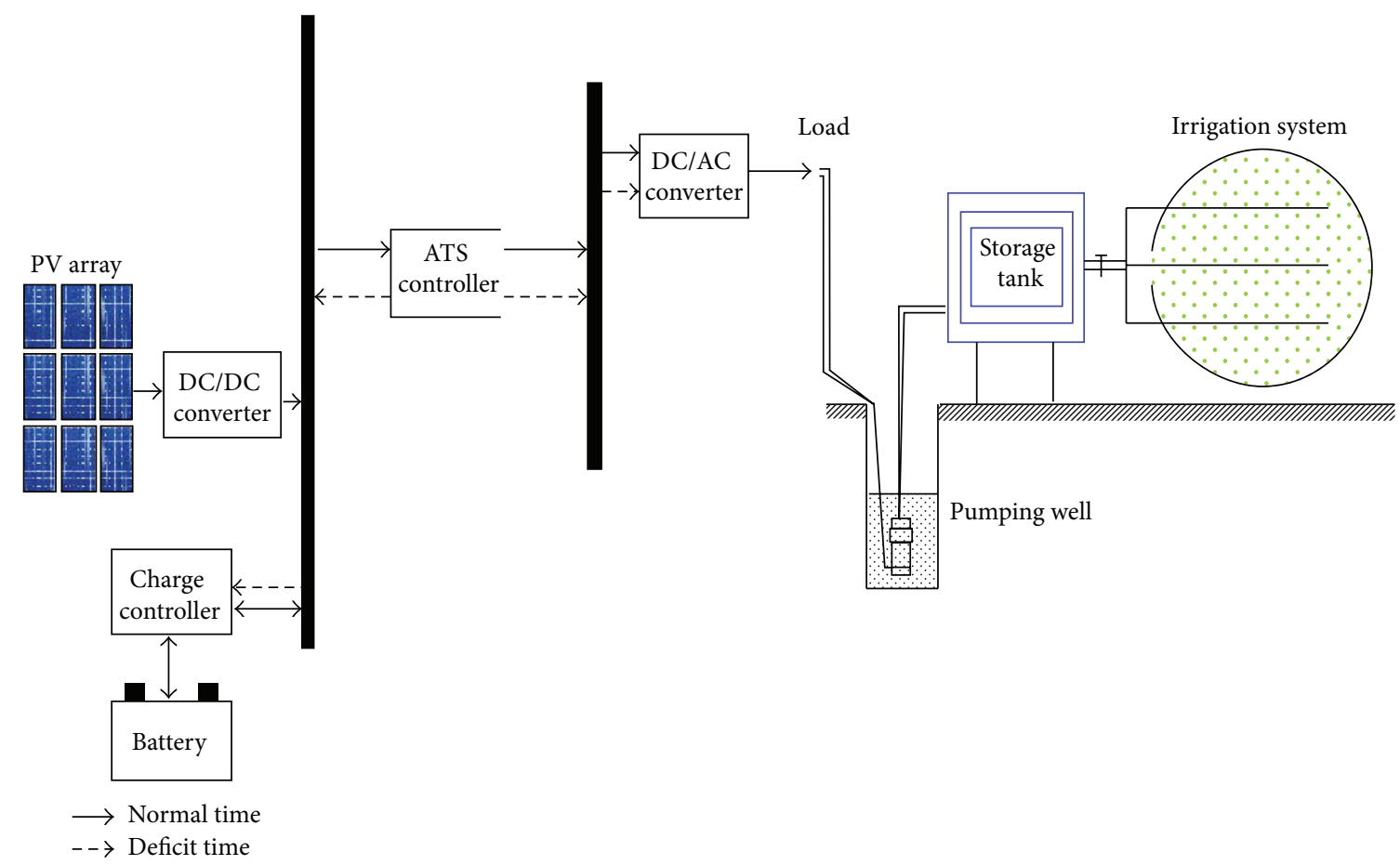

FIGURE 4: PV/water pumping system configuration.

4.3. Charger Controller and Inverter. The charger controller and inverter are electrical convert circuits which are used to convert electric power from DC to DC and AC, respectively. The lifetime of converters is up to 15 years with $94 \%$ efficiency and estimated price of an inverter is USD $0.5 / \mathrm{W}$.

4.4. Battery. Batteries are used to store the energy produced by the PV array. The battery efficiency depends on the state of charge and discharge, which affect the life of the battery. Also, it is worth mentioning that HOMER software does not take into consideration variation in temperature or any degradation in battery performance. In addition batteries remain constant throughout their lifetime. The proposed battery has a $12 \mathrm{~V}, 200 \mathrm{Ah}$ capacity. Its lifetime is considered to be 12 years.

\section{Design and Assessment of Water Pumping Systems}

5.1. Technoeconomical Assessment Criteria. To assess the system technically and economically four criteria have been used in this study as follows.

(i) Technical criteria: capacity factor (CF) and yield factor (YF) are applied to evaluate the productivity of the proposed system.

(ii) Economic criteria: payback period (PBP) and the cost of energy (CoE) are used to assess the feasibility of the proposed system.

The ratio of actual annual energy output to the amount of energy the PV array would generate if it operates at full rated power $\left(P_{r}\right)$ for $24 \mathrm{~h}$ per day for a year represents the annual capacity factor which is calculated as follows:

$$
\mathrm{CF}=\frac{\mathrm{YF}}{8760}=\frac{E_{\text {PVannual }}}{\left(P_{R} \times 8760\right)} .
$$

Meanwhile, the daily, monthly, or annual net AC energy output of the system divided by the peak power of the installed PV array at STC represents the yield factor which is calculated as follows [12]:

$$
\mathrm{YF}=\frac{E_{\mathrm{PV}}(\mathrm{kWh} / \text { year })}{\mathrm{PV}_{\mathrm{WP}}(\mathrm{kWp})} .
$$

On the other hand, the cost of energy and payback period criteria are used to assess the system economically. The life cycle cost (LCC) of a PV system may also include costs for system design, installation labor, site preparation, operation, and maintenance costs. The life cycle cost is calculated as follows:

$$
\begin{aligned}
\mathrm{LCC}= & C_{\text {capital }}+\sum_{1}^{n} C_{\mathrm{O} \& \mathrm{M}} \cdot R_{\mathrm{PW}} \\
& +\sum_{1}^{n} C_{\text {replacement }} \cdot R_{\mathrm{PW}}-C_{\text {salvage }} \cdot R_{\mathrm{PW}} \cdot
\end{aligned}
$$

The different components taken into account in calculating LCC are as follows: capital cost $C_{\text {capital, }}$ replacement cost $C_{\text {replacement }}$, maintenance cost $C_{\mathrm{O} \& \mathrm{M}}$, and salvage value $C_{\text {salvage }} \cdot R_{\mathrm{PW}}$ represents the present value of each factor which is calculated using the future sum of money $\left(F_{m}\right)$ in a given year $(N)$ at a given discount rate $(I)$ :

$$
R_{\mathrm{PW}}=\frac{F_{m}}{(1+I)^{N}} .
$$


TABLE 1: Modelled PV system specification.

\begin{tabular}{lc}
\hline \multicolumn{2}{c}{ PV array } \\
\hline PV module rated power & $140 \mathrm{Wp}$ \\
Maximum voltage & 17.7 \\
Maximum current & 7.91 \\
Open circuit voltage & 22.1 \\
Short circuit current & 8.68 \\
Efficiency & $13.9 \%$ \\
Temperature coefficient of Vo.c & $-0.36 \% / \mathrm{k}$ \\
Temperature coefficient of Is.c & $0.06 \% / \mathrm{k}$ \\
\hline \multicolumn{2}{c}{ Inverter } \\
\hline Rated power & $0.8 \mathrm{~kW}$ \\
AC voltage & $220-240$ \\
Efficiency & $94.0 \%$ \\
\hline
\end{tabular}

TABLE 2: Economic assumption of PV system.

\begin{tabular}{lccccc}
\hline Component & $\begin{array}{c}\text { Capital } \\
(\$ / \mathrm{kW})\end{array}$ & $\begin{array}{c}\text { Lifetime } \\
\text { (years) }\end{array}$ & $\begin{array}{c}\text { Replacement } \\
(\$)\end{array}$ & $\begin{array}{c}\text { O\&M } \\
(\$)\end{array}$ & $\begin{array}{c}\text { Fuel } \\
(\$)\end{array}$ \\
\hline PV & 1440 & 25 & 0 & 0 & 0 \\
Inverter & 400 & 15 & 150 & 0 & 0 \\
Battery & 560 & 12 & 487 & 256 & 0 \\
\hline
\end{tabular}

After calculating LCC, the cost of energy is calculated using

$$
\mathrm{CoE}=\frac{\mathrm{LCC}}{\sum_{1}^{n} E_{\text {PVannual }}},
$$

where $E_{\mathrm{PVannual}}$ is the annual energy production of the PV system, while $n$ is the system lifetime in years. Finally, the payback period is calculated as follows:

$$
\mathrm{PBP}=\frac{C_{\text {capital }}(\mathrm{USD})}{\left[E_{\mathrm{PVannual}}(\mathrm{kWh} / \text { year }) \times \operatorname{CoE}(\mathrm{USD} / \mathrm{kWh}) \times R_{\mathrm{PW}}\right]} .
$$

5.2. Optimum System Design. In this research solar water pumping system has been designed for irrigation in Sohar, Oman. This system contains $0.45 \mathrm{kWp}$ water pump. The system has been installed at Sohar zone for research work purposes. The feasibility of the proposed solar water pumping system was designed and analyzed using HOMER and REPS.OM to find the optimum system component. HOMER and REPS.OM were used to model different system elements and check the component physical behaviour and its life cycle cost. The optimum system components have been selected based on their technical and economic merits. Table 1 shows the specification of the optimum module and inverter.

The schematic diagram in HOMER model for the built PV system is presented in Figure 5. Since the solar radiation is high enough between 11:00 AM and 4:00 PM it is worth generating electricity in this period to supply the pump to fill the tank. The economic assumptions of the system and the load analysis calculation are given in Tables 2 and 3, respectively.
TABLE 3: Scaled data for simulation.

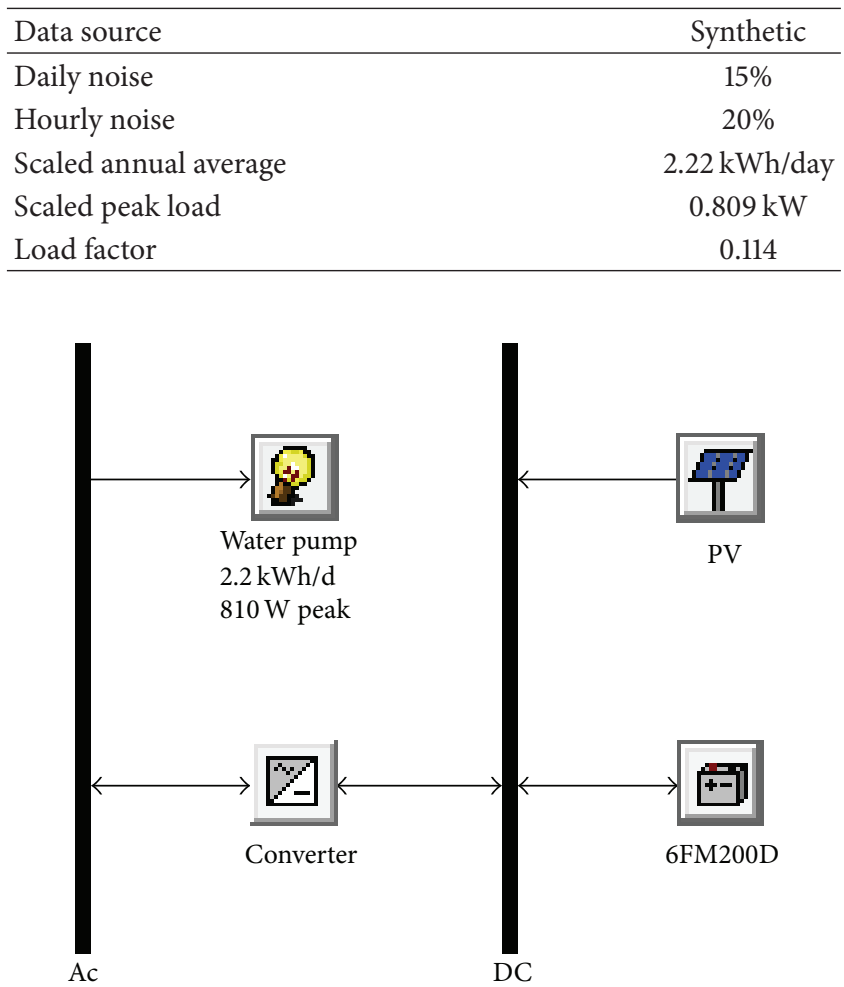

FIGURE 5: HOMER schematic diagram for the solar PV water pumping system.

The suggested PV module for simulation of the optimum system used in this study is $12 \mathrm{~V}, 140 \mathrm{Wp}$. Different PV module capacities are introduced and considered in the analysis which is in the range of 1-10 modules. The suggested battery was $12 \mathrm{~V}, 200 \mathrm{Ah}$ capacities with estimated cost of 140 USD. Also, for sensitivity analysis, the range of batteries is assumed to be 1-5 battery banks. Furthermore, the inverter efficiency was assumed to be $94 \%$ for all considered sizes with estimated cost of $0.5 \mathrm{USD} / \mathrm{W}$ and lifetime of 15 years. The inverter range was selected to be $0.1-1.0 \mathrm{~kW}$ for analysis consideration.

\section{Discussion and Analysis}

After running the system model in HOMER, 704 feasible solutions are found and out of these 10 best solutions ranked according to the system minimum net present cost (NPC) and cost of energy (CoE) are shown in Table 4. The table shows that the greatest optimal result is achieved when the system is composed of $0.84 \mathrm{~kW} \mathrm{PV}$ array (6 modules), 4 batteries, and $0.8 \mathrm{~kW}$ inverter. The optimum solution to the total NPC is 3,200 USD with operating cost of $63 \mathrm{USD} /$ year and the cost of energy equals $0.309 \mathrm{USD} / \mathrm{kWh}$. On the other hand, REPS.OM found that the optimum result is achieved when the system is composed of $0.56 \mathrm{~kW}$ PV array ( 4 modules), 2 batteries, and $0.45 \mathrm{~kW}$ inverter. Furthermore REPS.OM optimum solution found that the total NPC is 1,880 USD with operating cost of $33 \mathrm{USD} /$ year and the cost 
TABLE 4: Optimum solution for the proposed PV system using HOMER.

\begin{tabular}{|c|c|c|c|c|c|c|c|c|c|}
\hline 4 & $\begin{array}{c}\mathrm{PV} \\
(\mathrm{kW})\end{array}$ & 6FM200D & $\begin{array}{l}\text { Conv. } \\
(\mathrm{kW})\end{array}$ & $\begin{array}{l}\text { Initial } \\
\text { capital }\end{array}$ & $\begin{array}{l}\text { Operating } \\
\text { cost }(\$ / y r)\end{array}$ & $\begin{array}{l}\text { Total } \\
\text { NPC }\end{array}$ & $\begin{array}{c}\mathrm{COE} \\
(\$ / \mathrm{kWh})\end{array}$ & $\begin{array}{l}\text { Ren. } \\
\text { frac. }\end{array}$ & $\begin{array}{l}\text { Capacity } \\
\text { shortage }\end{array}$ \\
\hline 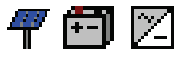 & 0.84 & 4 & 0.8 & $\$ 2,400$ & 63 & $\$ 3,200$ & 0.309 & 1.00 & 0.00 \\
\hline & 0.84 & 4 & 0.9 & $\$ 2,450$ & 64 & $\$ 3,265$ & 0.315 & 1.00 & 0.00 \\
\hline & 0.70 & 5 & 0.8 & $\$ 2,300$ & 76 & $\$ 3,269$ & 0.316 & 1.00 & 0.00 \\
\hline & 0.84 & 4 & 1.0 & $\$ 2,500$ & 65 & $\$ 3,331$ & 0.322 & 1.00 & 0.00 \\
\hline & 0.70 & 5 & 0.9 & $\$ 2,350$ & 77 & $\$ 3,335$ & 0.322 & 1.00 & 0.00 \\
\hline & 0.70 & 5 & 1.0 & $\$ 2,400$ & 78 & $\$ 3,400$ & 0.328 & 1.00 & 0.00 \\
\hline & 0.98 & 4 & 0.8 & $\$ 2,640$ & 63 & $\$ 3,440$ & 0.332 & 1.00 & 0.00 \\
\hline & 0.98 & 4 & 0.9 & $\$ 2,690$ & 64 & $\$ 3,505$ & 0.338 & 1.00 & 0.00 \\
\hline 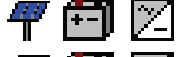 & 0.84 & 5 & 0.8 & $\$ 2,540$ & 76 & $\$ 3,509$ & 0.339 & 1.00 & 0.00 \\
\hline 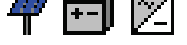 & 0.98 & 4 & 1.0 & $\$ 2,740$ & 65 & $\$ 3,571$ & 0.345 & 1.00 & 0.00 \\
\hline
\end{tabular}

of energy equals $0.18 \mathrm{USD} / \mathrm{kWh}$. It is worth mentioning that optimum tilt angle was found to be $27^{\circ}$ for Sohar.

The fossil fuel generator has been simulated for comparison to supply the same water pump as shown in Figure 6. There are different types of generators commercially available (propane, diesel, biofuel, and gasoline). In this study, the diesel fuel generator has been used, since it is more efficient and has a longer lifetime in comparison with others and because it is the used fuel in Oman as it is considered as one of the suppliers of fuel. Rural Areas Electricity Company (RAECO) generation system fuel is diesel. Its diesel price is subsidies from the Omani Government and accounted for 46 Baiza/Litre, which is equivalent to $0.38 \mathrm{USD} /$ Litre [12]. On the other hand it is found that global diesel price on January 2014 is 1.38 USD/Litre [13]. In this part the water pump system supplied from diesel generator has been investigated for comparison with designed PV systems.

The fuel price tested 0.38 and 1.38 USD/Litre with and without the government subsidy, respectively. The price of the generator is 500 USD and we considered the generator size of $500 \mathrm{~W}$ in the analysis. To compare the PV system results with the diesel generator to choose the best and costless system, the analysis shows that a size of $1000 \mathrm{~W}$ generator has been estimated with capital, operating, and total net cost being 1000 USD, 562 (USD/yr), and 8,185 USD, respectively, as shown in Table 5. The CoE is found to be 0.79 (USD/kWh), which is considered to be high as compared with CoE of the proposed PV system (0.18 and 0.309 (USD/kWh)).

The energy generated shares from REPS.OM proposed system are shown in Figure 7. PV system availability is calculated as the percentage of time that a power system is capable of meeting load requirements, where it is found that the system availability is $98 \%$. It is found that REPS.OM optimum system availability is higher than HOMER and intuitive method systems. However, Figure 7 shows the complete year performance of the proposed system. From the figure, it is clearly seen that the solar energy covers most of the system load and the battery is intensively used through the year, time which makes it able to supply the load in some extremely

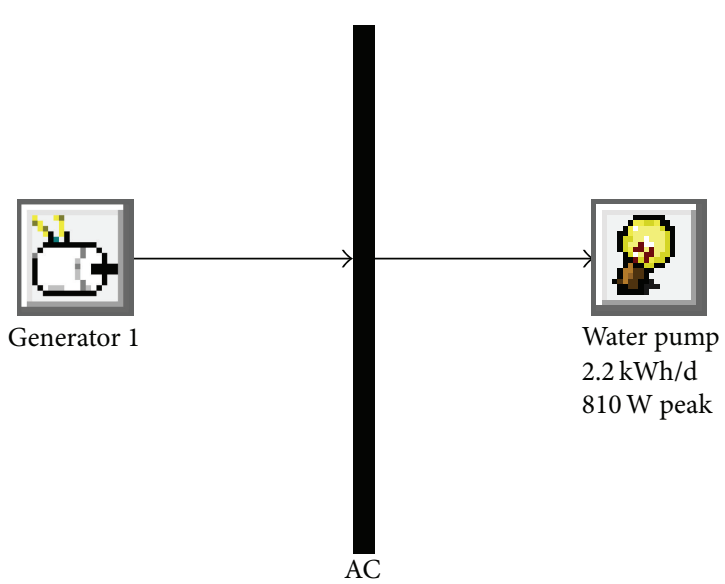

FIGURE 6: HOMER schematic diagrams for the diesel generator water pumping system.

cloudy days. However, it is found that the system annual yield factor is $2024.66 \mathrm{kWh} / \mathrm{kWp}$. Furthermore, the capacity factor was found to be $23.05 \%$, which is promising since the typical one is $21 \%$.

Emission of green-house gases from the fuel of the equivalent conventional system is important. Adopting solar PV systems will protect the environment from the harmful green-house gases. Table 6 shows the polluted emissions produced by the diesel generator used to supply the water pump. Furthermore, in comparison between subsidized and nonsubsidized fuel cost it is found that the $\mathrm{CoE}$ is 0.79 and 1.228 USD/kWh, respectively. This means that besides the protection of the environment the cost of diesel is relatively high and part of the cost covered by the government could be used for other economic projects if the PV technology has been adopted.

The comparisons of the cost of energy in the modelled system are shown in Table 7 . The proposed system cost is acceptable in comparison with the cost of PV systems in 
TABLE 5: Diesel system results for 0.38 USD/Litre.

\begin{tabular}{|c|c|c|c|c|c|c|c|c|c|}
\hline$\sqrt{2}$ & $\begin{array}{l}\text { Label } \\
(\mathrm{kW})\end{array}$ & $\begin{array}{l}\text { Initial } \\
\text { capital }\end{array}$ & $\begin{array}{l}\text { Operating } \\
\text { cost }(\$ / y r)\end{array}$ & $\begin{array}{l}\text { Total } \\
\text { NPC }\end{array}$ & $\begin{array}{c}\mathrm{COE} \\
(\$ / \mathrm{kWh})\end{array}$ & $\begin{array}{l}\text { Ren. } \\
\text { frac. }\end{array}$ & $\begin{array}{l}\text { Capacity } \\
\text { shortage }\end{array}$ & $\begin{array}{c}\text { Diesel } \\
(\mathrm{L})\end{array}$ & $\begin{array}{l}\text { Label } \\
\text { (hrs) }\end{array}$ \\
\hline & 1.0 & $\$ 1,000$ & 562 & $\$ 8,185$ & 0.790 & 0.00 & 0.00 & 351 & 1,825 \\
\hline
\end{tabular}

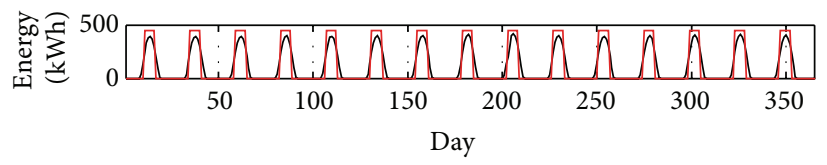

- Generated energy by PV

_ Load demand

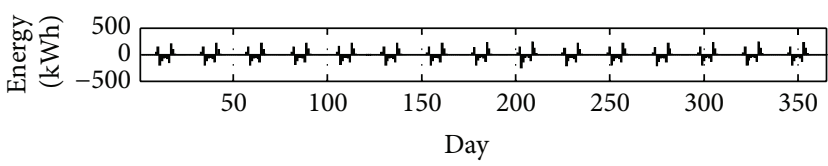

Energy balance
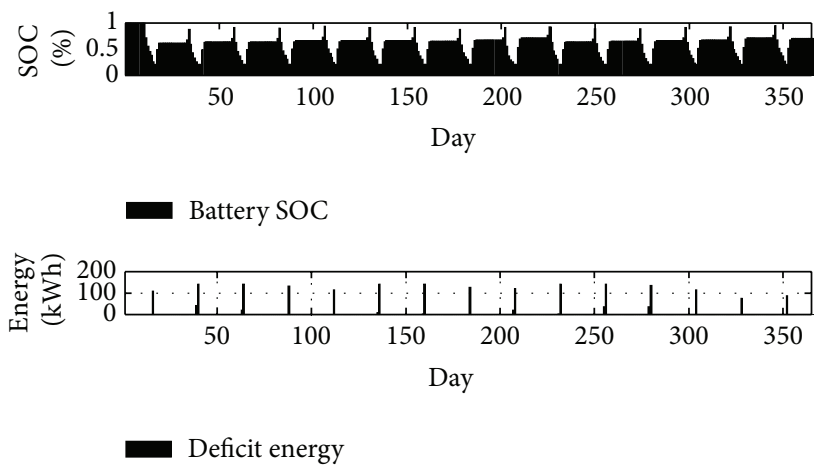

FIGURE 7: Proposed system hourly performance sample.

[4], [5], [6], [14], and [15], 0.401, 0.561, 0.389, 0.21-0.304, and $0.361-0.327 \mathrm{USD} / \mathrm{kWh}$, respectively. Also, it is found that the cost of PV systems is promising in comparison with the proposed diesel system ( 0.790 and $1.228 \mathrm{USD} / \mathrm{kWh}$ ) and the energy cost of diesel engine system in $[15,16] 0.5581$ USD/kWh. Furthermore, regardless of the fact that hybrid systems technically and economically are effective, it is found that the proposed PV system is economical in comparison with [8] where the cost of energy is $0.200-0.580 \mathrm{USD} / \mathrm{kWh}$, which make PV water pumping system be a good option for irrigation in rural areas of Oman.

\section{Conclusions}

In this study PV water pumping system for Sohar, Oman, has been designed and assessed. Optimum selection of system components, PV modules, inverter, charger controller, and batteries, Oman, has been determined. The system has a daily load of $2.22 \mathrm{kWh} /$ day, $0.84 \mathrm{~kW}$ PV modules, 4 batteries $(12 \mathrm{~V}$ and $200 \mathrm{Ah})$, and $0.8 \mathrm{~kW}$ inverter. The results have shown that the optimum cost of PV system energy 0.309 $\mathrm{USD} / \mathrm{kWh}$ is attractive option in comparison with the cost of diesel engine energy $0.79 \mathrm{USD} / \mathrm{kWh}$. Also, it is found that
TABLE 6: Diesel systems green-house gases emission.

\begin{tabular}{lc}
\hline Pollutant & Emission $(\mathrm{kg} / \mathrm{yr})$ \\
\hline Carbon dioxide & 924 \\
Carbon monoxide & 2.28 \\
Unburned hydrocarbons & 0.253 \\
Particulate matter & 0.172 \\
Sulfur dioxide & 1.86 \\
Nitrogen oxides & 20.4 \\
\hline
\end{tabular}

TABLE 7: Systems cost of energy comparison.

\begin{tabular}{lcc}
\hline Reference & $\begin{array}{c}\mathrm{CoE} \\
\text { (USD/kWh) }\end{array}$ & $\begin{array}{c}\text { Supply } \\
\text { type }\end{array}$ \\
\hline Proposed PV research (REPS.OM) & 0.180 & $\mathrm{PV}$ \\
Proposed PV research (HOMER) & 0.309 & $\mathrm{PV}$ \\
Subsidized diesel system & 0.790 & Diesel \\
Nonsubsidized diesel system & 1.228 & Diesel \\
([4] Bakelli et al., 2011) & 0.401 & $\mathrm{PV}$ \\
([5] Salam et al., 2013) & 0.561 & $\mathrm{PV}$ \\
([6] Kazem et al., 2013) & 0.389 & $\mathrm{PV}$ \\
([8] Al-Smairan, 2012) & $0.200-0.580$ & PV-diesel \\
([17] Al-Badi et al., 2011) & $0.21-0.304$ & $\mathrm{PV}$ \\
([14] Al-Badi et al., 2012) & $0.327-0.361$ & PV \\
([15] annual report, 2010) & 0.558 & Diesel \\
([16] annual report, 2011) & 0.558 & Diesel \\
\hline
\end{tabular}

most PV system options are feasible more than the diesel generator option. Also, investigations show that the proposed system is cost effective with designed systems in literature. In addition, it is found that PV solar water pumping systems could be an excellent option for irrigation in rural areas of Oman. Moreover, the analysis shows that replacing diesel generator by PV system will protect the environment from green-house gas emission $924 \mathrm{~kg} /$ year of $\mathrm{CO}_{2}, 2.28 \mathrm{~kg} /$ year of CO, $0.253 \mathrm{~kg} /$ year of NOx, $0.172 \mathrm{~kg} /$ year of HC, $1.86 \mathrm{~kg} /$ year of $\mathrm{SO}_{2}$, and $20.4 \mathrm{~kg} /$ year of suspended particles.

\section{Conflict of Interests}

The authors declare that there is no conflict of interests regarding the publication of this paper.

\section{Acknowledgments}

The research leading to these results has received Research Project Grant Funding from the Research Council of the Sultanate of Oman, Research Grant Agreement ORG SU EI 
11 010, and FURAP/C2/HK/ENGEE. The authors would like to acknowledge support from the Research Council of Oman.

\section{References}

[1] H. A. Kazem and T. Khatib, Photovoltaic Power System Prospective in Oman, Technical and Economical Study, LAP LAMBERT Academic Publishing, Saarbrücken, Germany, 1st edition, 2013.

[2] A. Al-Karaghouli and L. L. Kazmerski, "Optimization and lifecycle cost of health clinic PV system for a rural area in southern Iraq using HOMER software," Solar Energy, vol. 84, no. 4, pp. 710-714, 2010.

[3] Z. Girma, "Hybrid renewable energy design for rural electrification in Ethiopia," Journal of Energy Technologies and Policy, vol. 3, no. 13, pp. 38-52, 2013.

[4] Y. Bakelli, A. H. Arab, and B. Azoui, "Optimal sizing of photovoltaic pumping system with water tank storage using LPSP concept," Solar Energy, vol. 85, no. 2, pp. 288-294, 2011.

[5] M. A. Salam, A. Aziz, A. H. A. Alwaeli, and H. A. Kazem, "Optimal sizing of photovoltaic systems using HOMER for Sohar, Oman," International Journal of Renewable Energy Research, vol. 3, no. 2, pp. 301-307, 2013.

[6] H. A. Kazem, A. A. Alkurwi, M. M. Alabdul Salam, and A. H. A. Alwaeli, "Levelized electricity cost for photovoltaic system in Sohar-Oman," in Proceedings of the IEEE 8th International Conference and Exhibition on Ecological Vehicles and Renewable Energies (EVER '13), Monte-Carlo, Monaco, March 2013.

[7] R. Mishra and S. Singh, "Sustainable energy plan for a village in punjab for self energy generation," International Journal of Renewable Energy Research, vol. 3, no. 3, pp. 640-646, 2013.

[8] M. Al-Smairan, "Application of photovoltaic array for pumping water as an alternative to diesel engines in Jordan Badia, Tall Hassan station: case study," Renewable and Sustainable Energy Reviews, vol. 16, no. 7, pp. 4500-4507, 2012.

[9] K. Meah, S. Ula, and S. Barrett, "Solar photovoltaic water pumping-opportunities and challenges," Renewable and Sustainable Energy Reviews, vol. 12, no. 4, pp. 1162-1175, 2008.

[10] H. A. Kazem, T. Khatib, and K. Sopian, "Sizing of a standalone photovoltaic/battery system at minimum cost for remote housing electrification in Sohar, Oman," Energy and Buildings, vol. 61, pp. 108-115, 2013.

[11] H. A. Kazem, T. Khatib, K. Sopian, and W. Elmenreich, "Performance and feasibility assessment of a $1.4 \mathrm{~kW}$ roof top gridconnected photovoltaic power system under desertic weather conditions," Energy and Buildings, vol. 82, pp. 123-129, 2014.

[12] Authority for Electricity Regulation in Oman, "Study on renewable resources," Final Report, Authority for Electricity Regulation in Oman, Muscat, Oman, 2008.

[13] Fuel Price Report, 2014, http://www.catalist.com/.

[14] A. H. Al-Badi, M. AL-Toobi, S. AL-Harthy, Z. Al-Hosni, and A. AL-Harthy, "Hybrid systems for decentralized power generation in Oman," International Journal of Sustainable Energy, vol. 31, no. 6, pp. 411-421, 2012.

[15] Annual Report 2010, Rural Areas Electricity Company, Muscat, Oman, 2010.

[16] 2011 Annual report from Rural Areas Electricity Company, Oman.

[17] A. H. Al-Badi, M. H. Albadi, A. M. Al-Lawati, and A. S. Malik, "Economic perspective of PV electricity in Oman," Energy, vol. 36, no. 1, pp. 226-232, 2011. 

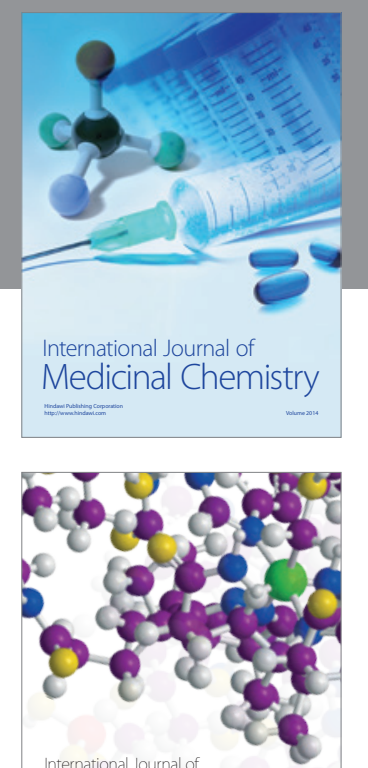

\section{Carbohydrate} Chemistry

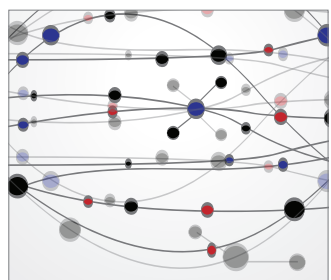

The Scientific World Journal
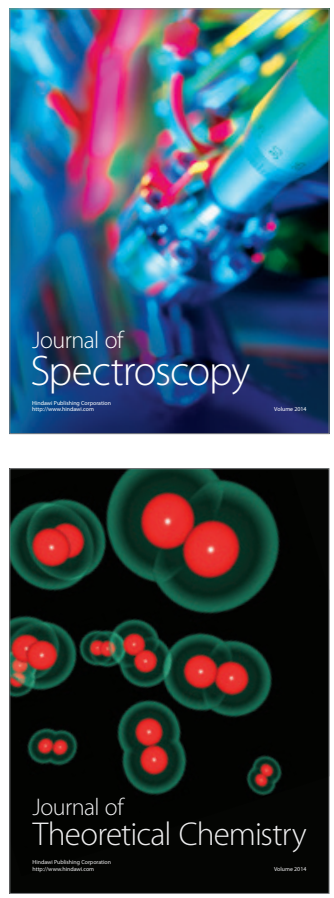
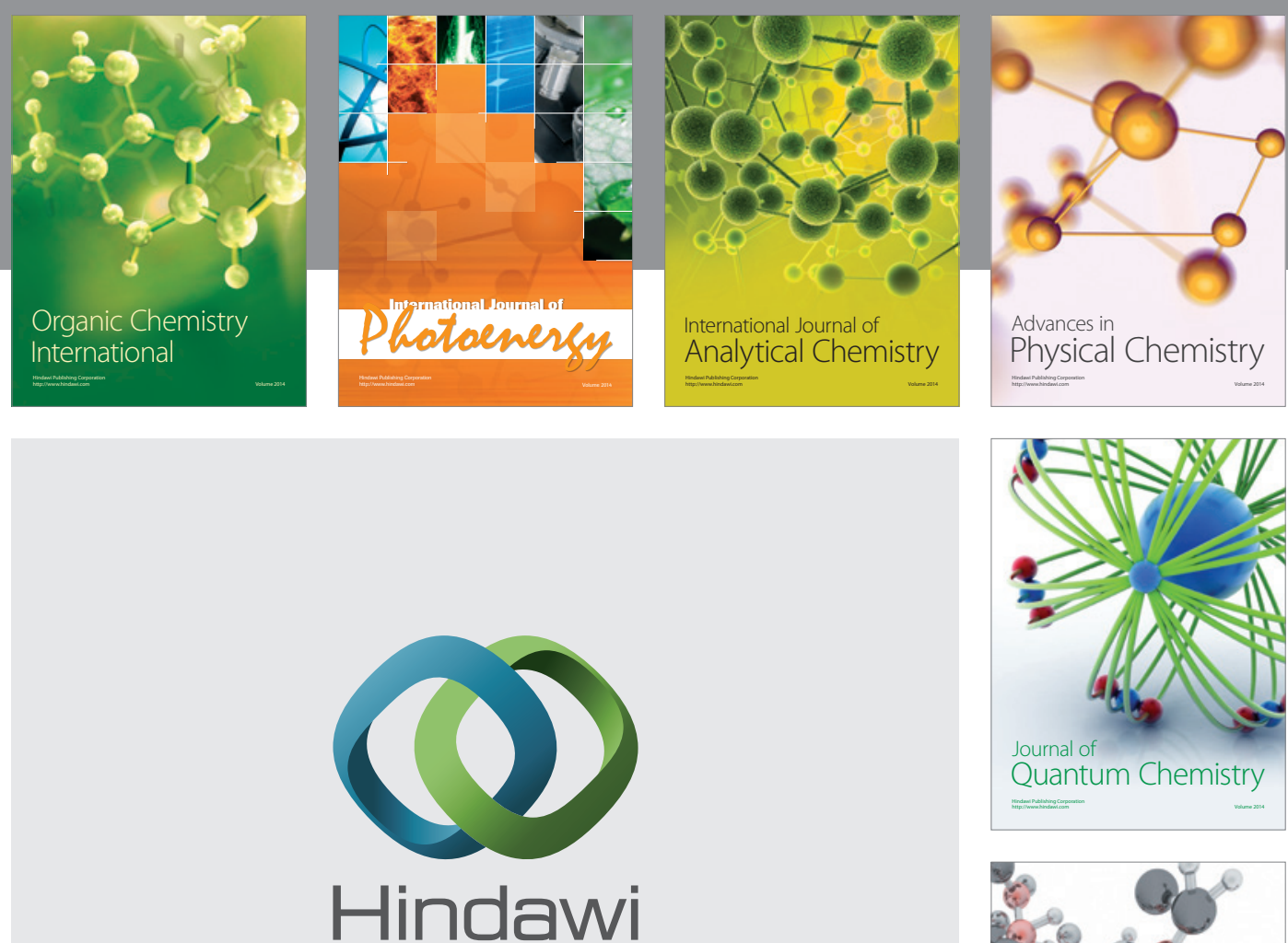

Submit your manuscripts at

http://www.hindawi.com

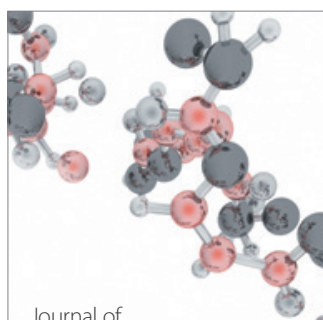

Analytical Methods

in Chemistry

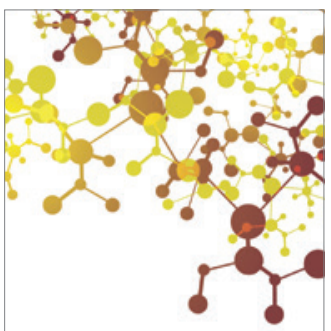

Journal of

Applied Chemistry

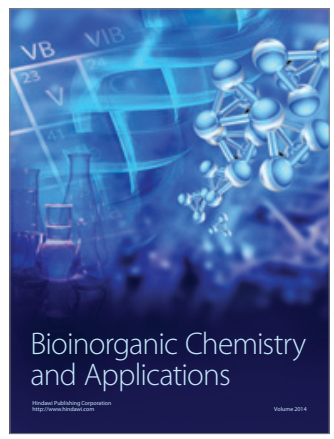

Inorganic Chemistry
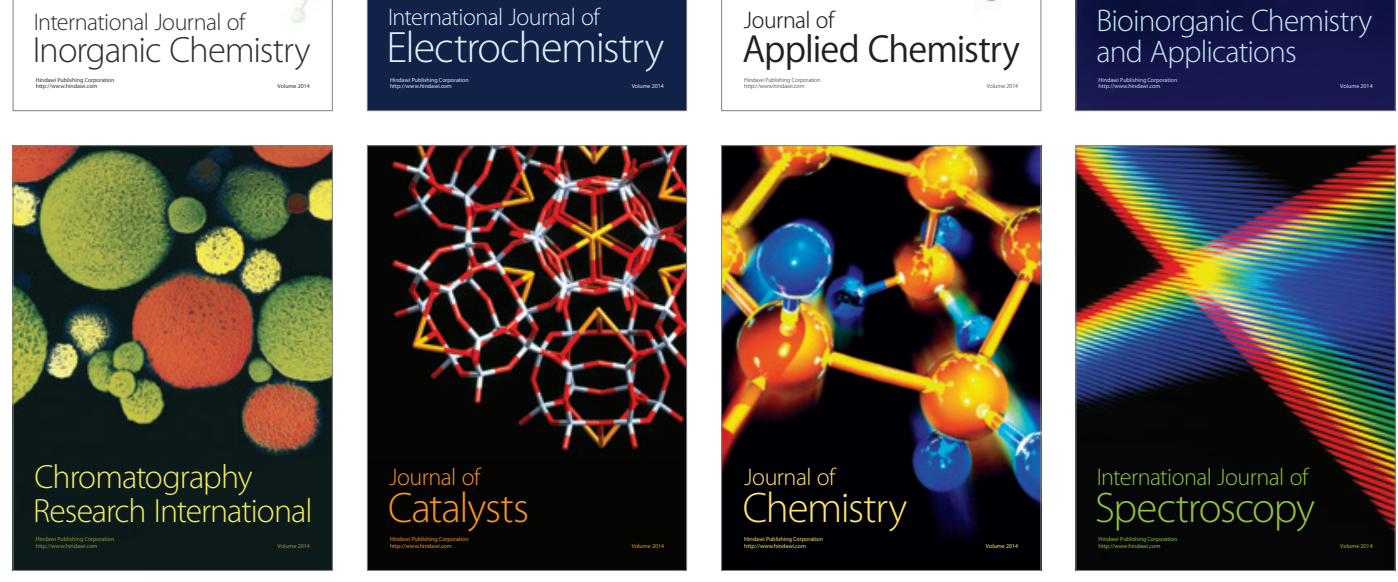